\title{
Neuropharmacological and antibacterial effects of the ethyl acetate extract of Diospyros malabarica (Ebenaceae) seeds
}

Tusnova Sharmin ${ }^{1}$, Razia Sultana ${ }^{2}$, Farzana Hossain ${ }^{3}$, Shahriar Kabir Shakil ${ }^{2}$, Foysal Hossen ${ }^{4}$ and Md. Mamun Or Rashid ${ }^{1 *}$ (D)

\begin{abstract}
Background: Diospyros malabarica is a well known flowering plant indigenous to Indian subcontinent which is used in folklore medicine for several purposes. Our study is designed to assess the neuropharmacological and antibacterial efficacy of the ethyl acetate extract of D. malabarica seeds.

Methods: The behavioral anxiolytic activities of the extract were assessed by using open field (OFT), hole cross $(H C T)$, elevated plus maze (EPZ), hole board (HBT), light dark test (LDT); and antidepressant activities through forced swimming (FST) and tail suspension test (TST). Antimicrobial potential was assessed through disc diffusion method.

Results: In OFT and HCT, the extract treated groups significantly $\left({ }^{*} p<0.05\right)$ decrease the movement of animals when compared to vehicle-treated group. Higher dose (400 mg/kg b.w.) of extract greatly increased the spending time in open arm of EPZ, which endorses anxiolytic-like behavior of extract. The observed effect may be due to binding of any phytoconstituent with GABA receptor. HBT and LDT results support the exploratory behavior of mice. The extract significantly decreased the immobility time in FST $(20.71 \%$ for $200 \mathrm{mg} / \mathrm{kg}$, and 31.59\% for $400 \mathrm{mg} / \mathrm{kg}$ extract) and TST, which indicates the occupancy of antidepressant-active constituents. Gram negative bacteria were susceptible to extract than Gram positive strains; however the antimicrobial effect is not significant, hence trivial to declare.

Conclusion: Our study demonstrates the possession of significant anxiolytic and antidepressant effects of $D$. malabarica extract which could be helpful for drug development program. Before potential therapeutic use, finding of the exact phytoconstituents with their mechanisms, and clinical trial are recommended.
\end{abstract}

Keywords: Anxiolytic, Antidepressant, Antibacterial, D. malabarica

\section{Background}

Although there is a great advancement of medical science, plants are still considered as important contributors of health care [1]. According to the assessment report of World Health Organization, approximately $80 \%$ of the people in the world (especially people of countryside areas) are still dependent on plant based medicine [2]. Last couples of decades, many phytopharmacological compounds have been isolated from the

\footnotetext{
* Correspondence: mamun_nstu@yahoo.com; mamun.orrashid@nstu.edu.bd ${ }^{1}$ Department of Pharmacy, Noakhali Science and Technology University, Sonapur, Noakhali 3814, Bangladesh

Full list of author information is available at the end of the article
}

plants; from which a significant number are used as potent therapeutic agents [3].

Diospyros malabarica is a medium size, long lived flowering tree belonging to the family of Ebenaceae, which is indigenous to indian subcontinent [4]. Various phytoconstituents are found from the individual parts of this plant- leaves contain triterpenes, betulin, $\beta$-sitosterol, oleanolic acid, myricyl alcohol; barks contain tannins, myricyl alcohol, triterpenes, betulinic acid, and saponin; fruits store alkanes, triterpenes, $\beta$-sitosterol, tannins, glucoside, betulin, betulinic acid, gallic acid, hexacosane, hexacosanol; and finally seeds possess $32 \%$ fatty oil, $\beta$-amyrin and betulinic acid etc. $[5,6]$. The plant parts are used in folklore medicine 
as astringent, anti-inflammatory, anti-fertility, hepatoprotective, antioxidant, and hypoglycemic agents [7, 8]. In addition, it is used for the treatment of dysentery, fever, and menstrual problems [9].

Although having several uses of D. malabarica, it was found through the literature review that there is no claim of research on neuropharmacological effects of the seed of this plant. Similar claim is also true for antimicrobial effectiveness test. The aim of our present study was to assess the neuropharmacological and antibacterial activities of the ethyl acetate extract of $D$. malabarica seeds.

\section{Methods}

\section{Drugs and reagents}

Diazepam, ciprofloxacin, imipramine were obtained from Sigma-Aldrich Corporation (USA). Ethyl acetate (Merck, Germany), and other chemicals necessary for experiment were analytical graded which were taken from the laboratory of Dept. of Pharmacy, NSTU, Bangladesh.

\section{Plant parts}

Fruits of $D$. malabarica were collected from Bahaddar hat, Chittagong, Bangladesh on november, 2016. After collection, fruits were washed thoroughly, and later authenticated by Naimur Rahman (Taxonomist, Bangladesh National Harberium, Dhaka, Bangladesh); and the specimen was kept there for future correspondence.

\section{Preparation of $D$. malabarica extract}

The seeds of $D$. malabarica after peeling the fruits were collected. Seeds were allowed to air-dry for 15 days period with shaded condition, which was followed by grinding into course powder. Crude powder materials were macerated into $2000 \mathrm{ml}$ ethyl acetate (>99\% pure) for 18 days at room temperature in a sterilized beaker which was wrapped by aluminum foil to avoid direct exposure of sunlight (cold extraction). After the incubation period, solution was filtered through filter cloth and later by Whatman filter paper. Filtrate was allowed to evaporate by the rotary vacuum evaporator under the reduced pressure to get concentrated semi-solid filtrate. After few days of drying in room temperature, we found the brownie granular sticky substance which was designated as crude ethyl acetate extract of D. malabarica [10].

\section{Experimental animals}

Swiss albino mice $(25 \pm 5 \mathrm{~g})$ were procured from the animal house of Jahangirnagar University, Bangladesh. These were kept in metal cages (condition: $20 \pm 5^{\circ} \mathrm{C}$ and light/dark cycle for $12 \mathrm{~h}$ ), and provided to feed on rodent foods and water ad-libitum from seven days before the commencement to finish the experiment.

\section{Test microorganisms}

We have used Staphylococcus aureus ATCC 25923, Salmonella typhi ATCC 14028, Escherichia coli ATCC 25922 and Pseudomonas aeruginosa ATCC 27853 for studying antibacterial activities; these strains were collected from the laboratory of the Department of Microbiology, Noakhali Science and Technology University (NSTU), Bangladesh.

\section{Behavioral studies of anxiolytic activities Open field test (OFT)}

The OFT apparatus was built using white plywood $(72 \mathrm{~cm} \times 72 \mathrm{~cm} \times 36 \mathrm{~cm})$. Mice can be seen from the outside wall (made by glass) of the apparatus. 16 squares were drawn on the floor for observing the movement of mice [11]. Mice were divided into four groups (each group consists of 5 mice): control (distilled water: $0.1 \mathrm{ml} / \mathrm{mice}$, oral), standard (diazepam: $1 \mathrm{mg} / \mathrm{kg}$ b.w. of mice, i.p.), D. malabarica (200 $\mathrm{mg} / \mathrm{kg}$ b.w. of mice, oral), and $D$. malabarica (400 $\mathrm{mg} / \mathrm{kg}$ b.w. of mice, oral). After administration of the respective doses, every mouse was observed for 3 min periods at the time of $(0,30,60,90$, and $120 \mathrm{~min}$ ) to count the number of squares crossed. After finishing a trail, the OFT apparatus was wiped by $(10 \%)$ ethanol for cleaning.

\section{Hole cross test (HCT)}

We have followed the process described by Hossain et al. for HCT [12]. A wood partition was set in center of the cage $(30 \mathrm{~cm} \times 20 \mathrm{~cm} \times 14 \mathrm{~cm})$. There was a hole (D$3 \mathrm{~cm})$ at $7.5 \mathrm{~cm}$ above from the ground in center of every partition. Animals were divided into four groups (each group consists of 5 mice): control (distilled water: $0.1 \mathrm{ml} / \mathrm{mice}$, oral), standard (diazepam: $1 \mathrm{mg} / \mathrm{kg}$ b.w. of mice, i.p.), D. malabarica (200 mg/kg b.w. of mice, oral), and D. malabarica (400 mg/kg b.w. of mice, oral). Number of transit of mice among the chambers through the hole was recorded for $3 \mathrm{~min}$ spell at $0,30,60,90$ and 120 min after administering the samples and drug.

\section{Elevated plus-maze (EPM) test}

EPM test is a widely accepting and authentic research study for finding the new drug with potential anxiolytic effects. The details methodology of this study was described in our previous paper, Rashid et al. [13]. The apparatus consists of two open arms $(35 \mathrm{~cm} \times 5 \mathrm{~cm} \times$ $35 \mathrm{~cm}$ ) crossed by two closed arms of similar size which are interconnected by a central square of $(5 \mathrm{~cm} \times 5 \mathrm{~cm})$. The experimental room was dimly illuminated, and EPM apparatus was kept on approx. $40 \mathrm{~cm}$ higher from the ground level. Experimental mice were grouped (each group consists of 5 mice) as control (distilled water: $0.1 \mathrm{ml} / \mathrm{mice}$, oral), standard (diazepam: $1 \mathrm{mg} / \mathrm{kg}$ b.w. of mice, i.p.), D. malabarica (200 mg/kg b.w. of mice, oral), 
and D. malabarica (400 $\mathrm{mg} / \mathrm{kg}$ b.w. of mice, oral). $1 \mathrm{~h}$ after treatment, animal was taken individually on the apparatus, and the number of entries in every arm was registered for $5 \mathrm{~min}$ spells. After finishing each session, EPM apparatus was cleaned by ethanol (70\%) and allow drying for few minutes.

\section{Hole board test (HBT)}

In HBT, head-dipping is generally considered as a measure of exploitation which is somehow distinct from the motor activity. An increase count of head dips compared to control is considered as anxiolytic-like effect. HBT was performed in a box $(40 \times 40 \times 25 \mathrm{~cm})$ made by wood with 16 equidistant holes (D- $3 \mathrm{~cm}$ ) was used in this experiment. Apparatus was kept at $35 \mathrm{~cm}$ above from the ground [14]. Mice were selected and grouped into 4 groups randomly (each group consists of 5 mice) and administered different samples accordingly. Mouse was kept on board, and its movement and head dipping in the hole was counted for $5 \mathrm{~min}$ duration. A single head-dip was counted when a mouse put into the hole at least up to the eye level; repeated dips into same hole were not consider as countable head dips if they can't be separated by locomotion.

\section{Light--dark transition (LDT) test}

LDT test is used for assessing anxiety-like behavior of animal. Natural aversion to bright illumination and exploration in mild stressors of the mice are the basis of this test. We have followed the process described by Hascoet and Bourin for this study [15]. LDT test apparatus consists of a box $(42 \mathrm{~cm} \times 21 \mathrm{~cm} \times 25 \mathrm{~cm})$, in where there are separated dark chamber and brightly illuminated chamber. Mice were taken in light compartment and allowed to move freely through a $(3 \mathrm{~cm} \times 4 \mathrm{~cm})$ opening. Animal were select randomly and provide the respective dosages accordingly. Then, the residual time in each chamber for every mouse were recorded.

\section{Antidepressant activity test}

Forced swimming test (FST) FCT is another common rodent behavioral model for the exploration of new antidepressant compounds. We have followed the FST method described by Con et al. with minor modification $[11,16]$. Cylindrical tanks $(30 \mathrm{~cm} \times 20 \mathrm{~cm})$ made of glass were used in where water level was kept almost $15 \mathrm{~cm}$ from the bottom of tank. We had recorded the immobile time of each mouse (time to keep the head above the water) for $360 \mathrm{~s}(6 \mathrm{~min})$. The last $240 \mathrm{~s}$ data from this recorded period were considered for analysis. Data was taken for each mouse of every group after treating with respective dosages. We used a stopwatch (can measure milliseconds) for counting time.
Tail suspension test (TST) TST (a well-known behavioral test of mice) method was adopted from Steru et al. [17]. TST box is made of plastic (Dimension: $55 \mathrm{~cm} \times$ $60 \mathrm{~cm} \times 11.5 \mathrm{~cm}$ ). Mouse was suspended from middle of the compartment, so that it can't attach with any wall. Mice were selected and grouped into 4 groups randomly (each group consists of 5 mice) and administered different samples accordingly. Mouse was hung by its tail which was attached on a string $(75 \mathrm{~cm}$ above the surface) by the help of adhesive tape. Immobile time was counted when mouse hung motionlessly. Observation was done for $6 \mathrm{~min}$ period; and the immobile time during this period was recorded.

\section{Antimicrobial activity test}

Antibacterial efficacy of the ethyl acetate extract of $D$. malabarica seeds were assessed through (Kirby-Bauer's disc diffusion method) by following Rashid et al. [18]. Samples were prepared by dissolving them in relevant solvents. Sterilized paper discs (D- $6 \mathrm{~mm}$ ) of the samples were impregnated into the swab plates (Muller-Hinton agar media) containing microorganisms $\left[2 \times 10^{6}\right.$ colony forming units $(\mathrm{CFU} / \mathrm{mL})]$. Aliquot of $50 \mu \mathrm{L}$ crude extract (concentration: $500 \mathrm{mg} / \mathrm{mL}$ ) was added in each disc. These plates were stand at $4{ }^{\circ} \mathrm{C}$ for $2 \mathrm{~h}$ which was followed by incubation at $37^{\circ} \mathrm{C}$ for $24 \mathrm{~h}$. Zone of inhibition (in millimeter) on the plates were measured for assessing the antibacterial efficacy of crude extract. Ciprofloxacin $(5 \mu \mathrm{g} /$ disc) and blank (solvents) discs served as positive and negative control respectively.

\section{Statistical analysis}

Data found in the experiment was analyzed statistically using one-way ANOVA followed by Dunnet's t-test. " $p \leq$ 0.05 was considered significant, whereas ${ }^{* * *} p \leq 0.001$ was highly significant value. Origin Pro (ver. 8.5, Origin Lab. Corp., USA) was used for preparing graphical pre sentations.

\section{Results \\ Open field test}

In the OFT, D. malabarica extract in both doses significantly $(" p<0.05)$ reduce the movement of mice when compared with control. Diazepam ( $1 \mathrm{mg} / \mathrm{kg}$ i.p.) also decreased the movement significantly. We found that suppression increases as time goes (Fig. 1). Maximum suppression was found at $120 \mathrm{~min}$ after the administration of dosages.

\section{Hole cross test}

The depressant activities of the ethyl acetate extract of D. malabarica seeds according to HCT method were shown in Fig. 2. It was found that movements of the mice treated by plant extract $(200 \mathrm{mg}$ and $400 \mathrm{mg} / \mathrm{kg}$ 


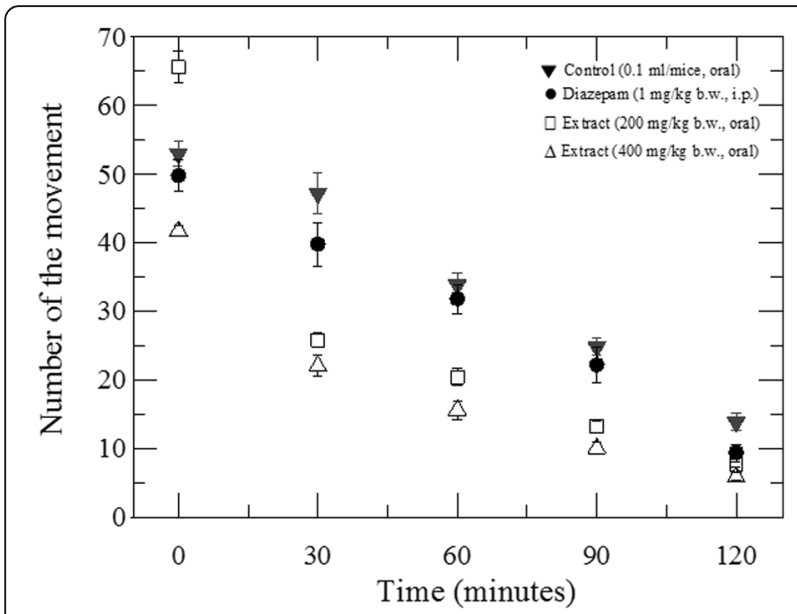

Fig. 1 Effect of the ethyl acetate extract of D. malabarica seeds in open field test

b.w. of mice, oral) decreased significantly from 2 nd observation $(30 \mathrm{~min})$ to 5 th observation $(120 \mathrm{~min}$ ) which is comparable with the reference drug diazepam $(1 \mathrm{mg} / \mathrm{kg}$ b.w., i.p.) (Fig. 2).

\section{Elevated plus maze}

The outcomes of the EPM test were shown in Table 1. It was found that diazepam ( $1 \mathrm{mg} / \mathrm{kg}$ b.w of mice, i.p.) significantly increased the spending times and entries in open arms when compared to control. Our tested crude extract at higher dosage $(400 \mathrm{mg} / \mathrm{kg}$ b.w. of mice, oral) significantly (" $p<0.05)$ increased the spending time and entries of mice in open arms of EPM apparatus.

\section{Hole board test}

Ethyl acetate extract of $D$. malabarica seeds decreased the number of head dipping when compared with control. The number of head dipping is $(12.17 \pm$

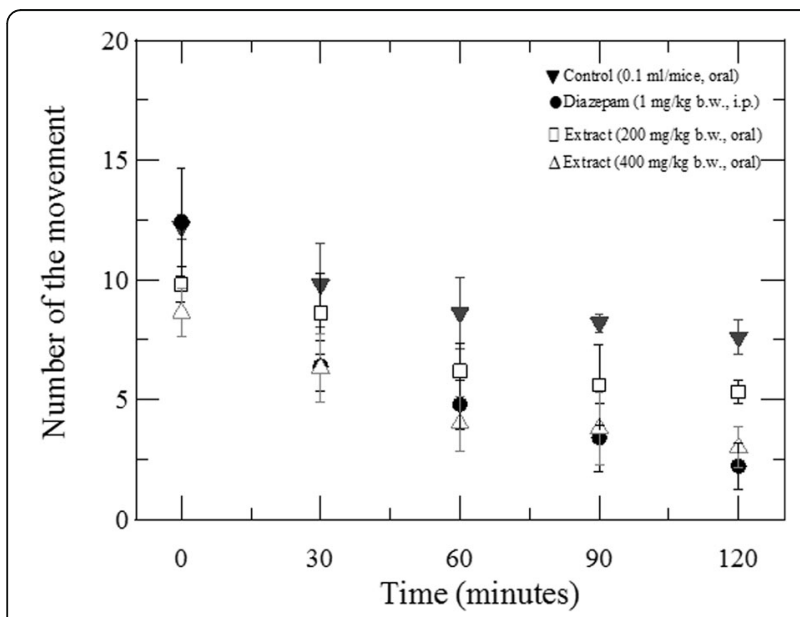

Fig. 2 Effect of the ethyl acetate extract of D. malabarica seeds in hole cross test of mice
Table 1 Effect of the ethyl acetate extract of D. malabarica seeds on EPM test

\begin{tabular}{llll}
\hline Group & Dose & $\begin{array}{l}\text { Time spent by mice } \\
\text { in open arms (sec) }\end{array}$ & $\begin{array}{l}\text { Entries of mice } \\
\text { in open arms }\end{array}$ \\
\hline $\begin{array}{l}\text { Distilled water } \\
\text { (control) }\end{array}$ & $0.1 \mathrm{ml} /$ mice (oral) & $93.87 \pm 3.73$ & $7.34 \pm 1.15$ \\
$\begin{array}{l}\text { Diazepam } \\
\text { (standard) }\end{array}$ & $\begin{array}{l}1 \mathrm{mg} / \mathrm{kg} \text { b.w. of } \\
\text { mice (i.p.) }\end{array}$ & $120.15 \pm 2.42^{* *}$ & $10.55 \pm 0.44^{*}$ \\
$\begin{array}{l}\text { D. malabarica } \\
\text { extract }\end{array}$ & $\begin{array}{l}200 \mathrm{mg} / \mathrm{kg} \text { b.w. of } \\
\text { mice (oral) }\end{array}$ & $78.65 \pm 2.13$ & $6.14 \pm 0.93^{*}$ \\
$\begin{array}{l}\text { D. malabarica } \\
\text { extract }\end{array}$ & $\begin{array}{l}400 \mathrm{mg} / \mathrm{kg} \text { b.w. of } \\
\text { mice (oral) }\end{array}$ & $111.24 \pm 3.54^{* *}$ & $9.89 \pm 1.62^{* *}$ \\
\hline
\end{tabular}

Mean \pm SEM $(n=5)$; One way ANOVA followed by Dunnet's t-test were performed. ${ }^{*} p<0.05,{ }^{* *} p<0.01$ as compared with control

1.73) for $200 \mathrm{mg} / \mathrm{kg}$ b.w., and $(4.48 \pm 1.02)$ for $400 \mathrm{mg} / \mathrm{kg}$ b.w of mice orally (significant) respectively; whereas this value was $(5.53 \pm 0.68)$ for standard (diazepam) (Fig. 3).

\section{Light -dark transition test}

D. malabarica extract (at both doses), and diazepam (standard) induced a significant $(* p<0.05)$ increment of spending time and number of transits in illumination side of LDT. Details results were shown in Table 2.

\section{Tail suspension test}

Administration of different dosages of ethyl acetate extract of $D$. malabarica seeds significantly $(" p<0.05)$ and dose dependently decrease the immobility time, which were comparable with imipramine (standard) (Fig. 4). The reductions of immobility time were $20.71 \%$, and $31.59 \%$ for 200 and $400 \mathrm{mg} / \mathrm{kg}$ dosages (plant extract) respectively which are comparable with the reduction of standard (40\%).

\section{Forced swimming test}

Table 3 shows the effect of $D$. malabarica on the immobility time of mice in FST. We found the dose dependent responses of our tested crude extract which were significant

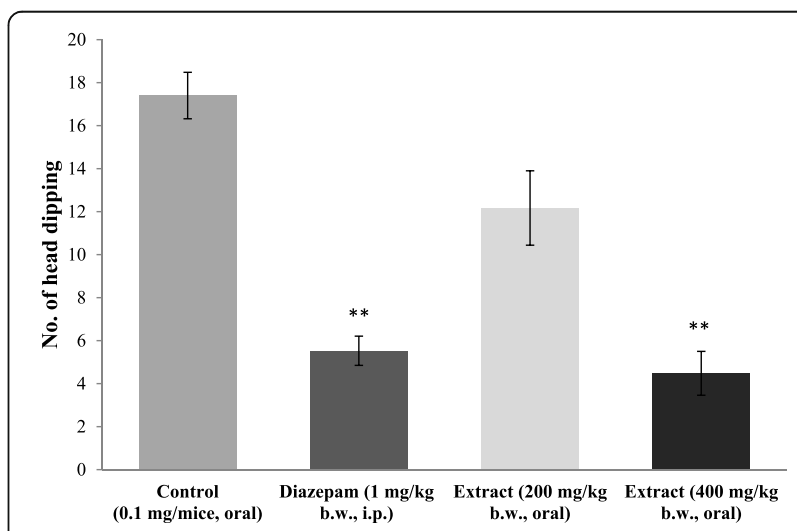

Fig. 3 Influence of the ethyl acetate extract of D. malabarica seeds in hole board test using mice model 
Table 2 Effect of D. malabarica extract in LDT test

\begin{tabular}{llll}
\hline Group & Dose & $\begin{array}{l}\text { Time (sec) spent by } \\
\text { mice in light box }\end{array}$ & $\begin{array}{l}\text { No. of } \\
\text { transitions of } \\
\text { mice }\end{array}$ \\
\hline $\begin{array}{l}\text { Distilled } \\
\text { water (control) }\end{array}$ & $\begin{array}{l}0.1 \mathrm{ml} / \mathrm{mice} \\
\text { (oral) }\end{array}$ & $74.40 \pm 3.36$ & $10.24 \pm 1.73$ \\
$\begin{array}{l}\text { Diazepam } \\
\text { (standard) }\end{array}$ & $\begin{array}{l}1 \mathrm{mg} / \mathrm{kg} \text { b.w. } \\
\text { of mice (i.p.) }\end{array}$ & $178.80 \pm 6.56^{*}$ & $9.73 \pm 2.45^{*}$ \\
$\begin{array}{l}\text { D. malabarica } \\
\text { extract }\end{array}$ & $\begin{array}{l}200 \mathrm{mg} / \mathrm{kg} \\
\text { b.w. of mice (oral) }\end{array}$ & $119.56 \pm 5.57$ & $14.44 \pm 2.36$ \\
$\begin{array}{l}\text { D. malabarica } \\
\text { extract }\end{array}$ & $\begin{array}{l}400 \mathrm{mg} / \mathrm{kg} \text { b.w. } \\
\text { of mice (oral) }\end{array}$ & $149.75 \pm 4.14^{* *}$ & $17.31 \pm 2.94^{*}$ \\
\hline $\begin{array}{l}\text { Mean } \pm \text { SEM }(n=5) ; \text { One way ANOVA followed by Dunnet's t-test were } \\
\text { performed. * } p<0.05, * * 0.01 \text { as compared with control }\end{array}$ &
\end{tabular}

when compared with control. Almost $(30.44 \pm 1.58)$, and $(57.55 \pm 2.73)$ sec immobility time were found for the crude extract of D. malabarica (200 mg/ $\mathrm{kg}$, oral), and (400 mg/kg, oral) b.w. of the mice respectively; whereas immobile time was $(30.44 \pm 1.58)$ for the standard drug (diazepam).

\section{Antimicrobial activity of crude extract}

In-vitro antibacterial efficacy test were performed for the ethyl acetate extract of $D$. malabarica seeds. Overall results (zone of inhibition produced) were summarized in (Table 4), (Fig. 5). We have followed disc diffusion method (conc. $0.1 \mathrm{ml} /$ disc) for studying the antibacterial activities of our tested extract using both Gram positive and Gram negative bacterial strains. Maximum zone of inhibition $(12.2 \pm 0.8 \mathrm{~mm})$ and $(8.9 \pm 0.3 \mathrm{~mm})$ were found for the extract when treated against the strains of E. coli and K. pneumonia respectively. Despite that, zone of inhibition was not noticeable for P. aeruginosa. Moreover, we didn't find the antibacterial efficacy for Gram positive bacterial species (S. aureus). The zones of inhibitions of the samples were compared with that of ciprofloxacin (Additional file 1).

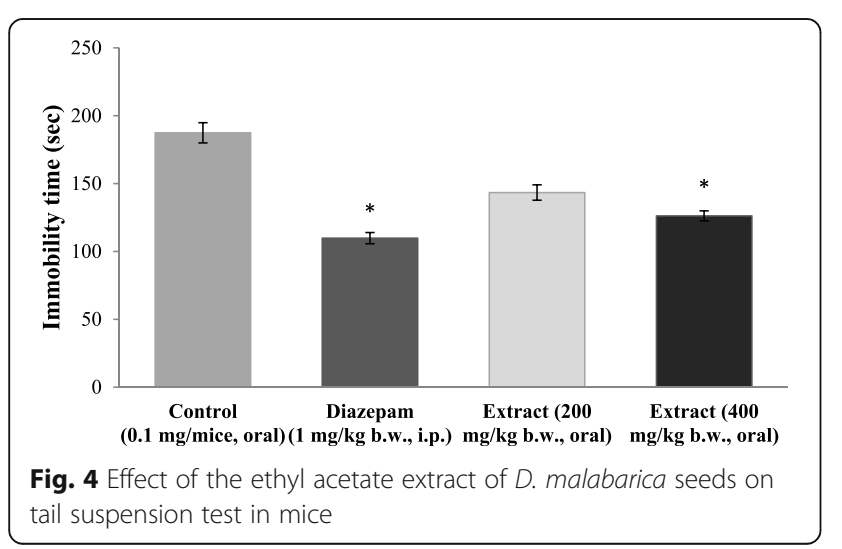

Table 3 Effect of the ethyl acetate extract of D. malabarica seeds on FST in mice

\begin{tabular}{lll}
\hline Group & Dose & $\begin{array}{l}\text { Immobility } \\
\text { time(sec) }\end{array}$ \\
\hline Distilled water (control) & $0.1 \mathrm{ml} /$ mice (oral) & $168.60 \pm 6.06$ \\
Diazepam (standard) & $1 \mathrm{mg} / \mathrm{kg}$ b.w. of mice (i.p.) & $30.44 \pm 2.54^{*}$ \\
D. malabarica extract & $\begin{array}{l}200 \mathrm{mg} / \mathrm{kg} \text { b.w. of mice } \\
\text { (oral) }\end{array}$ & $57.55 \pm 2.73^{* *}$ \\
& $\begin{array}{l}400 \mathrm{mg} / \mathrm{kg} \text { b.w. of mice } \\
\text { D. malabarica extract }\end{array}$ & $47.12 \pm 2.42^{*}$ \\
& (oral) & \\
\hline
\end{tabular}

Mean \pm SEM $(n=5)$; One way ANOVA followed by Dunnet's t-test were performed. ${ }^{*} p<0.05,{ }^{* *} p<0.01$ as compared with control

\section{Discussion}

Our study represents the first step to understand the effects of $D$. malabarica seed extract on CNS using mice model. We found that $D$. malabarica extract possesses significant anxiolytic, antidepressant, and explorative behavioral activities. In OFT and HCT, the extract treated groups significantly $\left({ }^{*} p<0.05\right)$ decrease the movement of animals when compared with vehicle treated group. Highest decrease was seen after 120 min of administrating the dosages; and this reduction was gradual and somehow follow dose dependent manner. According to the Mechan et al., OFT is a reliable method to assess the anxiety-like behavior characterized through the detestation of mice to bright lit open area. Anxiolytic agents can reduce such fearful attitude of mice in OFT $[19,20]$. Similarly reduction of the hole cross number was seen in HCT, where D. malabarica extract (both doses) decreased the spontaneous motor activities. As a result, it can be said that our tested extract possess significant anxiolytic-like effect. On the other hand, in EPZ experiment, the natural antipathy of mice to the open arm of EPZ apparatus indicates the anxiolytic-like effect of the compounds. We found that higher dose $(400 \mathrm{mg} / \mathrm{kg}$ b.w, oral.) of $D$. malabarica extract significantly increased the spending time in open arm of EPZ, which support the anxiolytic-like effect of the extract. Phytochemical

Table 4 Zone of inhibition of the ethyl acetate extract of $D$. malabarica seeds

\begin{tabular}{|c|c|c|}
\hline \multicolumn{3}{|c|}{ Zone of inhibition (mm) } \\
\hline Test organisms & $\begin{array}{l}\text { D. malabarica seed } \\
\text { extract }(500 \mathrm{mg} / \mathrm{mL})\end{array}$ & $\begin{array}{l}\text { Ciprofloxacin } \\
\text { (standard) }(5 \mu \mathrm{g} / \text { disc) }\end{array}$ \\
\hline \multicolumn{3}{|c|}{ Gram positive bacteria } \\
\hline S. aureus & 0 & $23.2 \pm 1.8$ \\
\hline \multicolumn{3}{|c|}{ Gram negative bacteria } \\
\hline E. coli & $12.2 \pm 0.8$ & $25.6 \pm 0.5$ \\
\hline K. pneumonia & $8.9 \pm 0.3$ & $25.6 \pm 1.3$ \\
\hline P. aeruginosa & 0 & $25.2 \pm 0.4$ \\
\hline
\end{tabular}

Mean \pm SEM $(n=5)$; One way ANOVA followed by Dunnet's t-test were performed. ${ }^{*} p<0.05,{ }^{* *} p<0.01$ as compared with control 

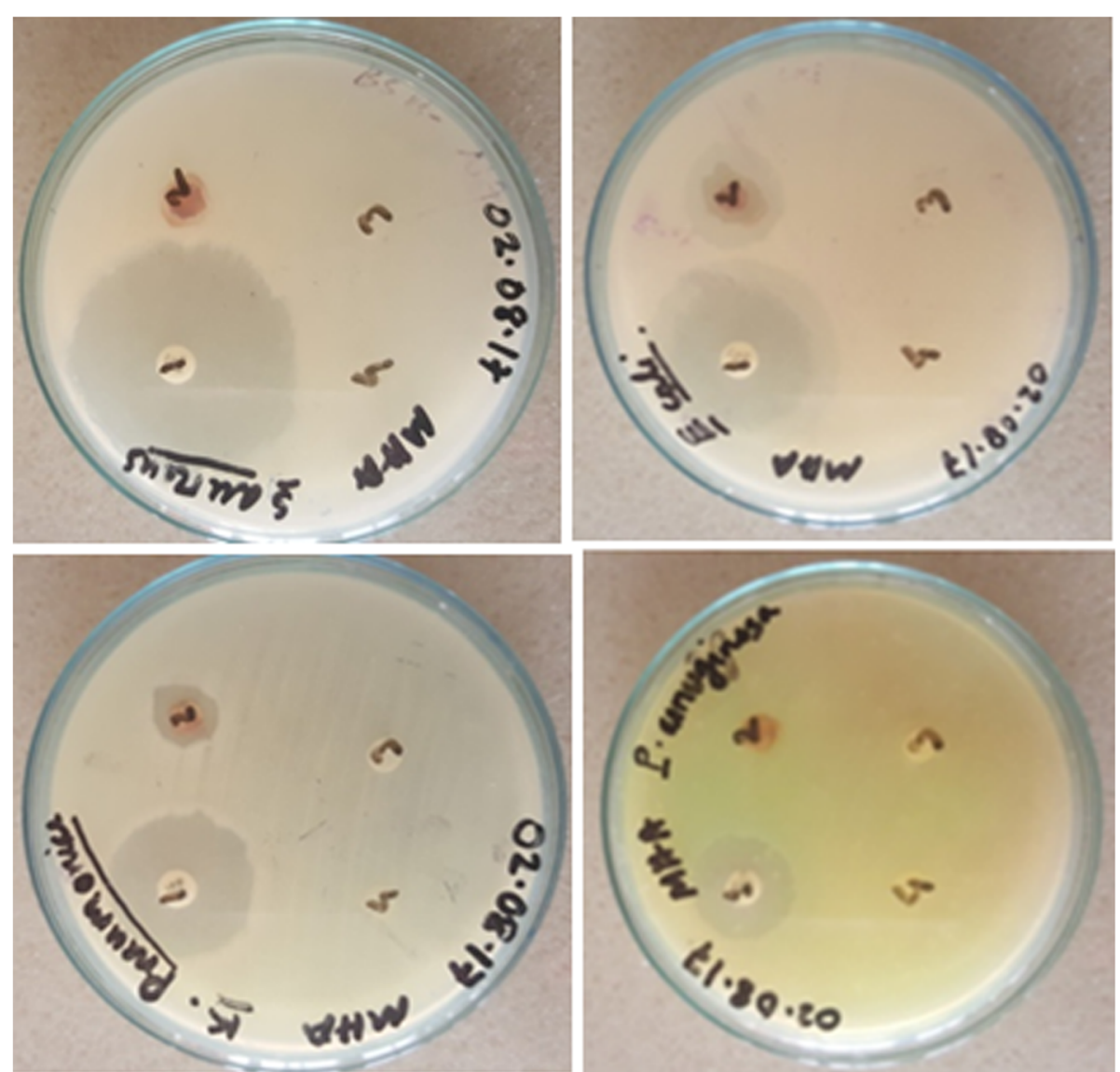

Fig. 5 Zone of inhibition of D. malabarica extract for different gram positive and gram negative bacterial strains

investigation claimed that $D$. malabarica extract possesses flavonoids, alkaloids, phenolic acids, essential oil, saponins, tannins etc. Presence of these phytoconstituent may responsible for CNS effects [21]. The effect may be due to hyperpolarization of CNS through interacting with gamma-amino-butyric acid $\left(\mathrm{GABA}_{\mathrm{A}}\right)$ receptor or benzodiazepine (BZD) receptor. GABA is the major inhibitory neurotransmitter of CNS, and most of the neurological drugs exert their anxiolytic effect by acting on $\mathrm{GABA}_{\mathrm{A}}$ receptor [22]. Therefore our hypothesis stand that anxiolytic activity of $D$. malabarica extract may be due to binding of any phytoconstituent with $\mathrm{GABA}_{\mathrm{A}}[21,22]$.

The anxiolytic-like effect of $D$. malabarica extract was also assessed using LDT box. We found that the mice treated with this extract spent more time in lightened side rather than darker one, which clearly indicates the possibility of having anxiolytic efficacy (transition parameter being highly dependent on locomotor activity) of the plants extract [23]. The effect may be due to agonistic effect of extract on GABA/BZD receptor complex, or antagonize 5-HT1B receptor, or agonize 5-HT1A receptor [20, 24]. In HBT, we found similar decreasing in exploratory behavior pattern of mice.

According to the Riaz et al., shortening of immobility period indicates antidepressant, and prolongation of this period symbolizes the CNS depression-like effect in FST and TST [25]. In both experiments, D. malabarica extract significantly decreased the immobility time which indicates the possession of antidepressant active constituents in extract. Approx. 20.71\%, and $31.59 \%$ of the reductions of immobility time were found for $200 \mathrm{mg} / \mathrm{kg}$ and $400 \mathrm{mg} / \mathrm{kg}$ doses (crude extract), which were comparable to the reduction of imipramine (40\%).

In-vitro antibacterial assay of $D$. malabarica extract has been studied. We found that ethyl acetate extract of this plant seeds possess slight antibacterial efficacy against Gram negative strains; however the effect is not significant. We didn't find any effect of extract on Gram positive strain. The differences of bacterial cell wall compositions may responsible for the variation of antibacterial effect. Perhaps, the antimicrobial effect was found due to the attachment of phytoconstituents (present in the extract) with cell proteins of bacteria, which was 
followed by the disruption of microbial protein synthesis $[18,22]$. Our results partially support the finding of Taranath et al., although the observed antibacterial effect is not significant to declare according to our experimental result [26].

\section{Conclusion}

In conclusion, based on our experimental data it can be said that mice treated with ethyl acetate extract of $D$. malabarica seeds offered significant antidepressant and anxiolytic activities. However, the antimicrobial effect of this extract is trivial to declare. For confirming the neurological effects and using as potential source of drug, further researches especially clinical trial is suggested of this plant part.

\section{Additional file}

Additional file 1: Zone of inhibition produced by D. malabarica seed extract. (XLSX $11 \mathrm{~kb})$

\section{Abbreviations}

BZD: Benzodiazepine; D. malabarica: Diospyros malabarica; EPZ: Elevated plus maze; FST: Forced swimming test; GABA: Gamma amino butyric acid; HBT: Hole board test; HCT: Hole cross test; LDT: Light dark test; OFT: Open field test; TST: Tail suspension test

\section{Acknowledgements \\ Authors are grateful to the staffs (technical/non-technical) of the Dept. of Microbiology, and Dept. of Pharmacy, NSTU, Bangladesh for giving valuable support and lab facilities during research works. In addition, heartiest thanks to the authority of $J \cup$, Bangladesh for providing mice during this research.}

\section{Funding}

TS got fund from the institutional research budget (Noakhali Science and Technology University, Bangladesh) for conducting this research work as part of her graduation degree.

\section{Author's contributions \\ Study design and writing of the manuscript were done by MMOR. TS, and $\mathrm{FH}$ participated in all the experiments under the supervision of MMOR, except antibacterial efficacy test. RS, and SKS activity participated into the antibacterial test where FH guided them. RS, and SKS helped to improve the writing, and revised the manuscript in current version. All authors read and approved the final version of the manuscript.}

\section{Ethics approval and consent to participate}

During experiments, 'Principles of the laboratory animal care' $(\mathrm{NIH}$ publication no. 85-23, revised 1985) and 'national animal care laws' were strictly followed. The study plan and performance of the research were approved by the institutional ethical committee.

\section{Consent for publication}

Not applicable.

\section{Competing interests}

The authors declare that they have no competing interests.

\section{Publisher's Note}

Springer Nature remains neutral with regard to jurisdictional claims in published maps and institutional affiliations.

\section{Author details}

'Department of Pharmacy, Noakhali Science and Technology University, Sonapur, Noakhali 3814, Bangladesh. ²Department of Biotechnology and Genetic Engineering, Noakhali Science and Technology University, Sonapur, Noakhali 3814, Bangladesh. ${ }^{3}$ Department of Microbiology, University of Dhaka, Dhaka 1000, Bangladesh. ${ }^{4}$ Department of Microbiology, Noakhali Science and Technology University, Sonapur, Noakhali 3814, Bangladesh.

Received: 6 April 2018 Accepted: 25 July 2018

Published online: 18 September 2018

\section{References}

1. Calixto JB, Beirith A, Ferreira J, Santos AR, Cechinel FV, Yunes RA. Naturally occurring antinociceptive substances from plants. Phytother Res. 2000;14:401-18.

2. World Health Organization. WHO Guideline for the Assessment of herbal Medicines, WHO expert committee on specification for pharmaceutical preparation. In: Technical Report series No 863- Thirty fourth Report, Geneva. 1996.

3. Calixto JB. Efficacy, safety, quality control, marketing and regulatory guidelines for herbal medicines (phytotherapeutic agents). Braz J Med Biol Res. 2000;33:179-89.

4. Mondal SK, Chakraborty G, Gupata M, Mszumder UK. In-vitro antioxidant activity of Diospyros malabarica Kostel bark. Indian J Exp Biol. 2006;44:39-44.

5. Kaushik V, Saini V, Pandurangan A, Khosa RL, Parcha V. A review of phytochemical and biological studies of Diospyros malabarica. Int J Pharm Sci Let. 2013;2(6):167-9.

6. Ghani A. Medicinal plants of Bangladesh with chemical constituents and uses. In: $2^{\text {nd }}$ edition, Asiatic society of Bangladesh, 5 old secretariat road, Nimtali, Dhaka, Bangladesh; 2003.

7. Rode MS, Kalaskar MG, Gond NY, Surana SJ. Evaluation of anti-diarrheal activity of Diospyros malabarica bark extract. Bangladesh J Pharmacol. 2013:8:49-53.

8. Choudhary DN, Singh JN, Verma SK, Singh BP. Antifertility effects of leaf extracts of some plants in male rats. Indian J Exp Biol. 1990;28(8):714-6.

9. Chopra RN, Chopra IC, Handa KL, Kapur LD. Chopra's indigenous drugs of India. 2nd ed. Calcutta, India: Academic publishers; 1994. p. 505.

10. Haque SS, Rashid MMO, Prodhan MA, Noor S, Das A. In vitro evaluation of antimicrobial, cytotoxic and antioxidant activities of crude methanolic extract and other fractions of Sterculia villosa barks. J Appl Pharm Sci. 2014;4(03):35-40.

11. Amin KMR, Uddin MG, Rashid MMO, Sharmin T. New insight in neuropharmacological activities of Dioscorea alata. Discovery Phytomedicine. 2018;5(1):1-6.

12. Hossain MF, Talukder B, Rana MN, Tasnim R, Nipun TS, Uddin SMN, Hossen SMM. In vivo sedative activity of methanolic extract of Stericulia villosa Roxb leaves. BMC Complement Altern Med. 2016;16:398.

13. Rashid MM, Hussain MS, Rashid MMO, Halim MA, Sen N, Millat MS, Sarker MA. In vivo analgesic potential in swiss albino mice and in vitro thrombolytic and membrane stabilizing activities of methanolic extract from Suaeda maritima whole plant. Bagcilar Med Bull. 2017;2(1):13-8.

14. Salahdeen HM, Yemitan OK. Neuropharmacological effects of aqueous leaf extract of Bryophyllum pinnatum in mice. Afr J Biomed Res. 2006;9: 101-7.

15. Bourin M, Hascoët M. The mouse light/dark box test. Eur J Pharmacol. 2003:463(1-3):55-65.

16. Can A, Dao DT, Arad M, Terrillion CE, Piantadosi SC, Gould TD. The mouse forced swim test. J Vis Exp. 2012:59:3638.

17. Steru L, Chermat R, Thierry B, Simon P. The tail suspension test: a new method for screening antidepressants in mice. Psychopharmacology (Berl). 1985;85:367-70.

18. Rashid MMO, Akhter KN, Chowdhury JA, Hossen F, Hussain MS, Hossain MT. Characterization of phytoconstituents and evaluation of antimicrobial activity of silver extract nanoparticles synthesized from Momordica charantia fruit extract. BMC Complement Altern Med. 2017;17:336.

19. Mechan AO, Moran PM, Elliott M, Young AJ, Joseph MH, Green R. A comparison between dark Agouti and Sprague-Dawley rats in their behaviour on the elevated plus-maze, open-field apparatus and activity meters, and their response to diazepam. Psychopharmacology. 2002; 159(2):188-95. 
20. Thippeswamy BS, Mishra B, Veerapur VP, Gupta G. Anxiolytic activity of Nymphaea alba Linn in mice as experimental models of anxiety. Indian J Pharmacol. 2011:43(1):50-5.

21. Dolai N, Karmakar I, Kumar RBS, Haldar PK. CNS depressant activity of Castanopsis indica leaves. Orient Pharm Exp Med. 2012;12:135-40.

22. Maridass M, Ghanthikumar S, Raju G. Preliminary phytochemical analysis of Diospyros species. Ethnobot Leaflets. 2008;12:868-72.

23. Zaretsky DV, Zaretskaia MV, DiMicco JA. Characterization of the relationship between spontaneous locomotor activity and cardiovascular parameters in conscious freely moving rats. Physiol Behav. 2016;154:60-7.

24. Nishikava $\mathrm{H}$, Hata T, Funakami Y. A role for corticotropin-releasing factor in repeated cold stress-induced anxiety-like behavior during forced swimming and elevated plus-maze test in mice. Biol Pharm Bull. 2004;27:352-6.

25. Riaz M, Zia-Ul-Huq M, Ur-Rahman N, Ahmad M. Neuropharmacological effects of methanolic extracts of Rubus fruticosus L. Turk J Med Sci. 2014;44:454-60

26. Taranath TC, Hedaginal BR, Rajani P, Sindhu M. Phytosynthesis of silver nanoparticles using the leaf extract of Diospyros malabarica (desr.) Kostel and its antibacterial activity against human pathogenic gram negative Escherichia coli and Pseudomonas aeruginosa. Int J Pharm Sci Rev Res. 2015;30(2):109-14.

\section{Submit your manuscript to a SpringerOpen ${ }^{\circ}$ journal and benefit from:}

- Convenient online submission

- Rigorous peer review

- Open access: articles freely available online

High visibility within the field

- Retaining the copyright to your article

Submit your next manuscript at $\boldsymbol{\nabla}$ springeropen.com 